\title{
Supportive housing for homeless people in the context of the Brazilian drug policy: implementation evaluation
}

\section{| ${ }^{1}$ Adriana Pinheiro Carvalho, ${ }^{2}$ Juarez Pereira Furtado |}

Abstract: Supportive housing interventions based on the Housing First approach have been implemented in Brazil as part of drug policy. It is relevant to analyze the influence of local characteristics on the implementation degree of this kind of intervention in this national context. We conducted an implementation evaluation case study of a supportive housing Project, in Brasília/ DF. To describe the initiative we used official documents, participant observation of real and virtual environments, systematization of the perception of project workers/ managers and logic model. The project description was then compared with criteria based on the HF proposal parameters. The results indicate the appropriateness of the intervention to the fundamental principle of putting housing in the first place, using local solutions and adaptations. However, shortcomings in the management of comprehensive care and disintegration of the social policy network challenge the implementation of the social integration component of the proposal. Health and Social Care interface needs to be better analyzed and the original model better known in its context of origin.

> Keywords: Housing; Mental Health; Drugs; Homelessness; Implementation.

\author{
${ }^{1}$ Departamento de Saúde \\ Coletiva, Faculdade de Medicina, \\ Universidade de São Paulo. \\ São Paulo-SP, Brazil (adriana. \\ pinheirocarvalho@gmail.com). \\ ORCID: 0000-0001-9548-0577 \\ ${ }^{2}$ Departamento de Políticas \\ Públicas e Saúde Coletiva, \\ Universidade Federal de São \\ Paulo-SP, Brazil (juarezpfurtado@ \\ hotmail.com). \\ ORCID: 0000-0001-6605-1925
}

Received: 21/01/2020

Approved: 10/03/2020

Revised: 23/03/2021 


\section{Introduction}

The different political positions on the topic of drugs have important repercussions for the health care of people who use drugs (ALVES, 2009; CSETE et al., 2016; TEIXEIRA et al., 2017b; GOMES-MEDEIROS et al., 2019). On the one hand, the State's commitment to combating trafficking and consumption of illicit drugs strengthens the view that, for the health field, abstinence is the only condition, means and purpose of treating problems related to drug use (ALVES, 2009). On the other hand, there is the recognition that, although the possession of illicit substances is prohibited and harmful consumption patterns exist, the suppression of the demand for drugs in society is an illusory objective and that the establishment of abstinence as the only treatment goal tends to exclude people in need of health care (ANDRADE, 2011; CSETE et al., 2016), especially those from socially vulnerable groups, such as the homeless (BOURGOIS, 2010; RUI, 2014). This last perspective supported, at least until 2016 (LEAL; FERRARI, 2019), the position of the Brazilian government (BRAZIL, 2004; 2005; GARCIA et al., 2014) that public policies for people who use drugs must imperatively guarantee, for those who are unable or unwilling to interrupt consumption, access to social rights, including health and social assistance and housing goods and services.

The first national survey on the use of crack in Brazil (BASTOS; BERTONI, 2014), carried out in 26 Brazilian capitals and in the Federal District, revealed the social vulnerability of people who use crack in street scenes, a group that constitutes most of the total users of this drug in the country. They are young (average of 30.3 years), men (78.7\%), non-white (79.15\%), single (60\%), with low education $(80 \%$ did not reach high school), without regular work (only $12.39 \%$ have regular work), without fixed housing (46\%) and with a history of passing through the prison system (48.8\%). Contamination by the HIV virus, in this group, is eight times greater than in the general population, being even greater among women users. Most participants in the same survey also report limited access to health services, associating bureaucratic barriers and stigma as obstacles.

In both the Brazilian and the international literature, it appears that homelessness and drug use are conditions that often overlap (PAULY et al., 2013; TEIXEIRA et al., 2017a; HINO et al., 2018; VAN WIJK; MÂNGIA, 2018; SICARRI; ZANELLA, 2018), the damage from substance use possibly being aggravated when living on the 
streets and in hostels (CHENG et al., 2014; DIDENKO; PANKRATZ, 2007). Before starting drug use and living on the streets, most people often have precarious and unstable living conditions (MATS; 2008; FITZPATRICK et al., 2013; BASTOS; BERTONI, 2014; PIAT et al., 2015), and substance use may precede and be simultaneous with homelessness. Such evidence weakens the simplistic and stigmatizing view of the connection between drug addiction and homelessness and requires an expanded look at the objectives of drug policy that includes, in addition to the provision of health treatment, the reduction of the social impacts of consumption.

In this sense, international consensus (UNITED NATIONS, 2012; 2018) and national policies (BRAZIL, 2004; 2005) recognize that in the care of people with difficulties in accessing and adhering to health care, such as those who are homeless, the harm reduction approach and other social actions are absolutely strategic, ranging from basic offers such as shelter, food and personal hygiene, to comprehensive interventions that include housing associated with different levels of support that facilitate social inclusion.

Based on this perspective and in the results of the mentioned study on the consumption of crack in public spaces (BASTOS; BERTONI, 2014), the Federal Government has fostered, since 2014, within the scope of the National Drug Policy, the development of intersectoral initiatives focused on social inclusion for homeless people with problems related to drug use. Inspired by the international model of Housing First (TSEMBERIS et al., 2004), these initiatives sought to examine the provision of housing integrated with paid work opportunities for PSR, without requiring abstinence or adherence to treatments for joining or staying in projects (GARCIA et al., 2014).

Housing First (HF) emerged in the 1990s, in the United States, as a strategy for people with chronic homelessness (TSEMBERIS; 1999), a condition in which there is a long history of homelessness associated with serious mental health problems, including harmful drug use. Its main innovation, evident in its name, is the understanding that meeting the need for housing is a fundamental condition for the care of homeless people with mental health problems, regardless of their adherence to certain behaviors or drug consumption patterns. The model essentially seeks to overcome traditional practices based on the logic of progressive adherence and compliance steps as requirements to achieve permanent housing (PADGETT et al., 2016). In HF's perspective, housing cannot be conditioned to the solution of social 
and health problems. On the contrary, housing is a condition that allows and favors other problems to be addressed.

HF is basically structured around the simultaneous offer of two components Individual housing and Psychosocial support, housing and social integration, being recognized as assisted housing, a type of housing service developed in the late 1980s as a response to the closure of psychiatric hospitals, to meet the housing demand of people with mental disorders (TABOL et al, 2010). The housing must be permanent, in individual or congregated units (several individual units in the same building), with support actions based on the principles of psychosocial rehabilitation and harm reduction (TSEMBERIS et al., 2004).

Driven by a body of evidence that points to the effectiveness of HF in increasing the length of stay of homeless people in homes, compared to traditional hostel services, the model was widely implemented in the United States and Canada and is currently also under development in European countries and Australia (PADGETT et al., 2016). However, recent studies point out barriers to the program implementation process which challenge their consistency with the original model, especially regarding harm reduction practice (WATSON et al., 2017) and other contextual factors as funding, organizational structure and human resources (MACNAUGHTON et al., 2015; LANCIONE, 2018).

To carry out the study presented here, we started from the assumption that the set of initiatives encouraged by the Brazilian federal government, in 2014/2015, was a relevant field of learning and source of knowledge to understand how this approach modality - Housing First - develops in the context of Brazilian public policy. Thus, we define the implementation process as a central attribute to be evaluated, that is, to analyze how and to what extent one of these interventions was implemented as conceived. For this objective, we used the methodological framework of Implementation Analysis (CHAMPAGNE et al., 2011a).

\section{Method}

We analyzed, by means of a single case study, the implementation of a pilot intervention for assisted housing for homeless people developed in the city of Brasília (Brazil's federal capital) - Project Taking Care of Life (PTC), carried out by the local government department of social assistance in partnership with a non- 
governmental organization. The initiative was part of the set of projects funded by the National Drug Policy Secretariat (NDPS) to pilot the Housing First approach and was developed for nineteen months throughout 2017/2018.

Implementation analysis, which favors the identification of factors that facilitate or hinder the introduction of theoretical proposals in real contexts, is one of the aspects of evaluative studies (HARTZ, 1997; CHAMPAGNE et al., 2011a). In this perspective, our aim was to know the dynamics of PTC functioning and to identify its degree of implementation through the analysis of its structural (human and physical resources) and contextual (practices, interactions and local socio-political factors) elements.

Using triangulation (MINAYO, 2005), we established several sources of information to carry out the proposed analysis, using a qualitative framework (FURTADO, 2006) and participatory research (BRANDÃO, 2006; FURTADO; ONOCKO-CAMPOS, 2008). We conducted participant observation, document analysis, Shared Appraisal Groups (SAG) with professionals and project managers and we developed the Operational Logical Model for PTC. Finally, we compared our systematized information with a Criteria Matrix to measure the degree of implementation of the project and to identify the factors - barriers and facilitators - that influenced it.

We analyzed documents from the federal plan (NDPS's standardization matrix and technical guidelines describing the program); local management (terms of reference, monitoring and inspection reports); and the project itself (technical operational project, collective field diary and beneficiaries' medical records), with attention to the objectives present in the documents, to the criteria presented for the implementation and evaluation of the intervention and to the concepts, principles and notions that conform the guiding parameters of the proposal.

Using the notion of experience and context (LEJANO, 2012), the fieldwork consisted of monitoring the daily routine of the intervention, experiencing the practices and interactions produced in it, through participant observation, and conducting Shared Appreciation Groups (SAG) with professionals directly involved in the project. During five months, 100 hours of immersion in the field were carried out to monitor four members of the outreach team responsible for supporting the residents - two workers working with a harm reduction approach and two combining 
social work and healthcare skills. We used field notebooks and short audio recordings to record the impressions and reflections of the observation activity, later used in the production of field diaries, plus other information, impressions, photos and aspects arising from the meetings with the intervention team.

Prior to the research, the main researcher had been part of the social context of the intervention given her condition as a professional in the mental health network of the community where the intervention studied was developed. The participant observation was carried on through the interaction with the agents of the field during home visits carried out together with the technical team in which informal dialogues, questions and participation in support activities for the residents were maintained.

We sought to observe the care practices and resources used by the team (techniques, type of interaction, network of services triggered), the structure of the houses (physical space and ambience) and the experience of the residents (interaction with the team / owners / neighbors / community and use of the house). In the two Shared Appraisal Groups (SAP), we sought to identify the components of the project's operational model and understand the difficulties faced in the implementation and the proposals for improving the theoretical model. The SAPs were constituted as spaces for mediating the participation of those involved in the research process, contributing to the construction of a broader interpretative framework for the evaluation (FURTADO et al., 2013).

Another observation locus was the virtual space where daily experiences, events, opinions and decisions were taken by the group of workers within the project fieldworkers, coordinators of the NGO implementing the project and the supervisor from the local department of social assistance (MARKHAM, 2005).

The set of initiatives aimed at understanding and describing the present study object constituted the basis on which we elaborated the PTC modeling. For this, we compiled a logical model of the program - a strategy widely advocated and discussed within the evaluation of programs and services (CHEN, 1990; CHAMPAGNE et al., 2011b) - outlining its resources, activities and products. The logical model was discussed and verified with the project team, establishing a consensus on what constitutes the intervention and offering an occasion for the debate on the issues arising from day-to-day experiences.

Considering that the federal government's proposal for the PTC had HF as a model, we have adopted fidelity dimensions and criteria used in the evaluation of HF 
programs in different contexts in the United States and Canada (STEFANCIC et al., 2013) to structure the matrix of criteria for the degree of implementation of the program, adding specific elements of the Brazilian proposal. The convergence between the principles of the two proposals - harm reduction, psychosocial rehabilitation and intersectoral action with a territorial and community basis - allowed us to use them to identify any variations suffered in the implementation of the project.

Our matrix is composed of five dimensions: choice and structure of housing, adaptation to the criteria for accessing housing and staying housed, assumptions and technical guidelines of the intervention, care management and intersectoriality and organization of work processes. We used the score proposed by Nelson et al (2014) which defines values on a standardized scale that ranges from 1 (low degree of implementation) to 4 (high degree of implementation), with scores 1 and 2 representing challenges to implementation and 2 and 4 opportunities / facilities.

The modeling and dense description of the intervention, together with the records produced in the field, were approached according to the interpretative method, grouped into categories related to the dimensions of the criteria matrix and in other thematic categories emerging from the field.

\section{Results and discussion}

\section{Project Characterization}

The Federal District's social assistance department received financial resources from the federal government to implement 30 units of assisted housing for street drug users, through ta project carried out in partnership with a social assistance NGO. The project lasted for nineteen months, from April 2017 to November 2018, and the target audience was made up of a group of homeless people belonging to a central region of Brasilia known for being a scene of drug use and trafficking.

The projects components were progressively organized and are represented in the Logical Operational Model. 
Figure 1. Logical Operational Model of the Project

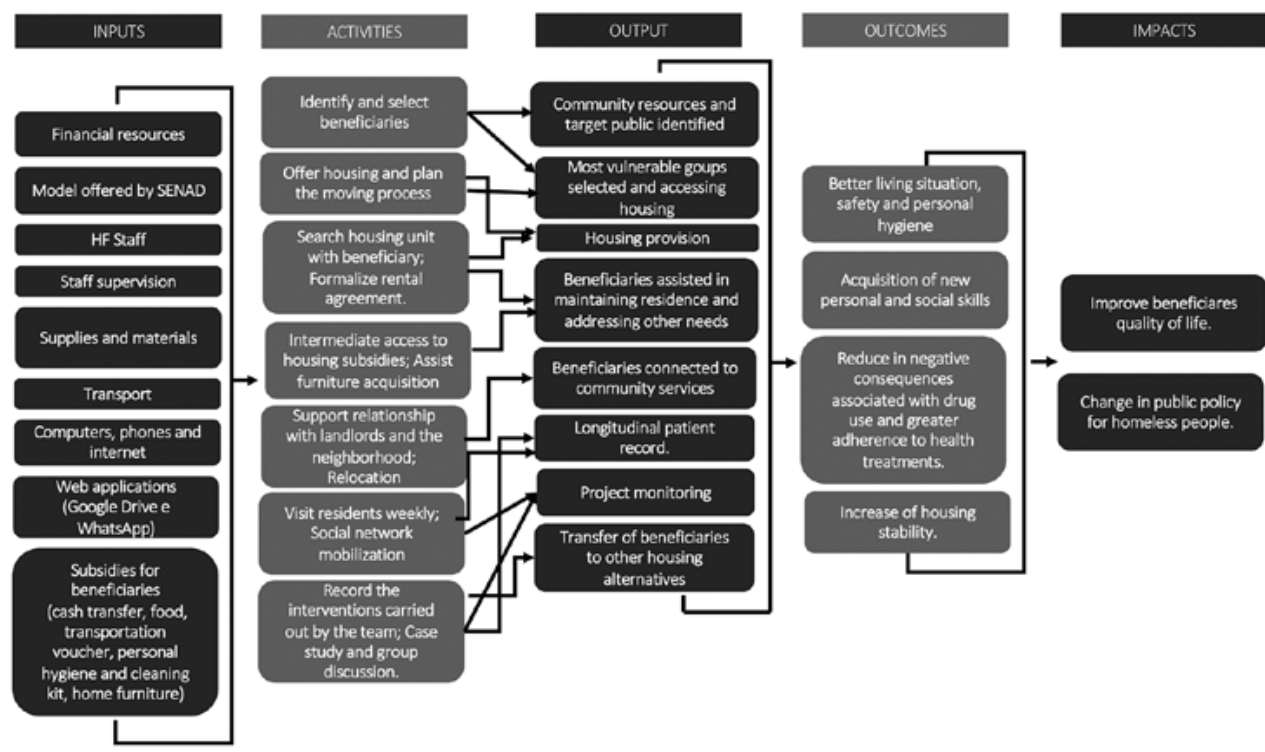

Source: the authors.

The first stage of the intervention lasted 03 months and was dedicated to the assembling and training of the team -1 coordinator, 1 administrative assistant, 4 harm reduction workers, 4 health/social agents, 3 facilitators with life experience of homelessness and 1 institutional clinical supervisor. The next stage was dedicated to exploring and mapping the area and its resources, identifying the target population, influential stakeholders and building trust strategies to link with them. After that, the team selected beneficiaries, implemented rent contracts, gave support for structuring the housing units (furniture etc.) and established a routine to support the beneficiaries. Next, we describe the functioning of the project. This description was the basis for the attribution of scores in the analysis of the degree of implementation, shown in Table 1.

\section{Selection of participants}

The experience of chronic homelessness, characterized by a long period of living on the streets - over five years - associated with harmful use of drugs and / or mental disorder, was the main criterion for the inclusion of beneficiaries in the project. This profile was defined taking into account experiences of the HF model developed 
in Canada (GOERING et al., 2014) in which the beneficiaries had multiple needs resulting from drug use and the presence of a mental disorder. During the execution, new inclusion criteria were introduced by the project team, responding to the demands of the local population, such as women victims of violence and pregnant women. In all cases participants were required to commit to participating in a weekly meeting with their reference team, which was formalized in a written contract. There was no requirement to adhere to treatment for substance misuse or to other criteria such as abstinence, sobriety, use of medication, symptom stability and absence of criminal involvement.

The fieldwork of the research started in the 12th month of the project's execution, when 22 people had been inserted in the assisted housing, 13 men and 9 women, aged between 24 and 54 years old. All of them had been homeless for more than five years and used predominantly alcohol and crack, 8 had previously been in jail and 5 had a diagnosis of severe mental disorder. Among the participants, there was a family with three children and a couple with two babies.

\section{Choice and structuring of housing units}

The search and choice of houses was carried out by the reference team, together with future residents, seeking to meet their preferences regarding the neighborhood and the type of housing. In a few cases, houses were used by more than one ensuing participant. Mostly, the properties were made up of small residential units, inserted in urban neighborhoods of the Federal District, in small plots shared by several households, having a private bedroom, bathroom and kitchen, and communal laundry, if any. The negotiation of the rent values and conditions was carried out directly by the project team with the owners and the monthly payment made by the NGO.

The possibility of choosing the property was restricted to the amount available for each rent, a ceiling around US\$ 110.00 per month established by local legislation (DISTRITO FEDERAL, 2014), and acceptance of the profile of future residents, by the owners, who were informed about the project. In some cases, tenants established verbal rules for not using drugs on the premises. Participants were included in the residential units in less than two months after joining the project.

The purchase of minimal furniture and household items was not financed by the federal government. As an alternative for the purchase of the aforementioned items, 
it was foreseen to grant cash value to the residents, passed on directly by the social assistance department. However, normative obstacles limited the process and, in several cases, it was impossible to structure the houses at the appropriate time. The cost of water, energy and other basic needs - personal hygiene and cleaning - was estimated to be borne by the residents, when possible, with their own resources and/ or using other government allowances. Food was provided by a local government program which distributes a monthly provision of items to people in need.

\section{Support to new residents}

The follow-up, conducted by reference pairs (health/social worker and harm reduction worker), had the purpose of favoring adaptation and permanence in the new housing context and was essentially characterized by weekly home visits, previously arranged with the residents. However, to meet other project demands or problems related to the residents themselves, this schedule was altered, sometimes without previous communication. On average, the project maintained weekly faceto-face contact with $80 \%$ of the participants.

In moments of interaction with residents, the team provided guidance aimed at developing domestic skills, health care habits (personal hygiene, preservative and contraceptive methods, use of prescribed medications, adequate food, reduced drug use and maternal child care) and planning for the use of financial resources from social benefits received. When interacting with property owners and neighbors, professionals often mediated conflicts with residents. On the other hand, significant relations of cooperation between owners, neighbors and residents were also established, such as medication control, food preparation and intermediation of communication with the team.

Residents, to some extent, were also accompanied in their itineraries, in social assistance and social security services, in search of social benefits and, eventually, in consultations at mental health and addiction community clinics and other specialized health units (HIV / AIDS). However, there was little integration with these services, in the sense of implementing shared monitoring plans that went beyond the provision of specific and fragmented services. The participation of residents in activities related to work, education, culture / sport was practically nonexistent. In a few cases, informal conversations and support actions between residents and neighbors were identified. In general, it was noticed that, in the daily lives of the residents, the project team was 
the main and commonly the only focal point for tasks of housing, health and social support, without the aid of professionals from other services or areas.

The non-attendance at health and other services agreed during the follow-up did not influence the stay in the house. Residents could refuse to participate in the support services provided, except for the weekly home visit. The team often encouraged residents to reduce drug use, without requiring withdrawal behaviors. However, it was noticed that the professionals did not have operational resources (transportation and workload) and technical repertoire (clinical skills) to intensify the care provided to residents and develop consistent proposals for community integration.

We observed that, in cases of conflict with the owner of the property or other events that caused the loss of housing, the residents were relocated, respecting the same structural pattern as the previous residence and with no limit on reallocations made by the participant. Two cases, one aggression on staff and a theft of neighbors, resulted in eviction without relocation. However, in these and other cases where housing was discontinued - hospitalization, prison and moving to live with family members - the participants continued to be followed by the team to keep on with other support initiatives and search for other housing options.

\section{Organization of work processes}

The project stipulated the proportion of three professionals - harm reduction, facilitator and health/social worker - to follow each ten residents. However, during the execution, the monitoring of all beneficiaries was effectively carried out by two pairs of workers (facilitators did not participate). The project did not provide a readiness structure to meet residents' demands on an uninterrupted basis, however, professionals often welcomed demands from participants outside working hours, on their phones and private social networks, and sought support networks for them.

The project coordination held regular meetings with the team, to discuss topics related to the project which were not exclusively focused on planning and evaluating the follow-up of residents. Very often decisions and referrals related to residents were made through telephone calls and exchanging messages in the team's virtual group. The discussion of cases occurred in a less systematic way with the participation of a psychologist from the specialized unit of social assistance for homeless people, in which agreements were also established for the granting of other social allowances. The team also had external supervision meetings, carried out approximately every 
three months. This training activity was conducted by a psychiatrist specialized in the addictions and focused on the clinical and institutional management of cases and the provision of emotional support for the team.

\section{Implementation analysis}

The following table (Table 1) presents the average score attributed to each of the dimensions of the evaluation matrix for the degree of implementation, the individual score by criterion and the elements that supported the judgment of each item. We measured the degree of implementation of the intervention at 2.87 , out of a possible total of 4.00. It is evident that the intervention is adapted to the fundamental assumptions of the theoretical model (housing first and harm reduction). On the other hand, there are challenges to implementation associated with the management of intersectoral actions and organization of work processes, especially in the implementation of actions aimed at the dimension of social and community integration. In these dimensions, the lack of interface with other expected sectors (health and work) and the difficulty in sustaining collective spaces for planning and discussing the activities developed by the team appear as critical factors, together with the low participation of residents in the evaluation and management of the project.

Regarding structural aspects, the proportion standards of residents per team worker were kept, as well as the inclusion of workers with previous homelessness experience were respected. The workload for follow-up activities, approximately 16 hours a week, was also below the 30 hours suggested in the theoretical model. About the condition of the houses, they generally respected the criteria established for privacy, community integration and costing value by the resident. In this dimension, the obstacle was the low capacity of the project to structure all houses with furniture and household items at the appropriate time for residents to move in.

In dimensions 1 and 2, in which the project achieved a satisfactory average of implementation ( $>3$ ), participants power to choose their place of residence, the quick availability of houses and the use of individual residential properties inserted in the community stand out. The adoption of criteria appropriate to the public for inclusion and permanence in homes, the non-requirement to adhere to health treatment services and the relocation of participants to other homes, when necessary, demonstrate high fidelity to the theoretical model, as well as the prioritization of people in chronic homelessness as the target for the project. 
Table 1. Implementation Evaluation Matrix. Brasília-DF, 2019

\begin{tabular}{|c|c|c|}
\hline $\begin{array}{l}\text { Dimension and } \\
\text { Criterion }\end{array}$ & Standards & $\begin{array}{l}\text { Score } \\
\text { obtained by } \\
\text { PCV }\end{array}$ \\
\hline $\begin{array}{l}\text { 1. Housing choice and } \\
\text { structure }\end{array}$ & & 3.33 \\
\hline $\begin{array}{l}\text { Housing and } \\
\text { neighborhood choice }\end{array}$ & $\begin{array}{l}\text { Participants must have a high possibility of choosing the } \\
\text { neighborhood, type of housing, decoration and other } \\
\text { elements related to the structure of the house. }\end{array}$ & 3 \\
\hline $\begin{array}{l}\text { Help to structure the } \\
\text { house }\end{array}$ & $\begin{array}{l}\text { Participants must receive support for the purchase of } \\
\text { furniture, household items and other decorative objects. }\end{array}$ & 2 \\
\hline $\begin{array}{l}\text { Prontidão na provisão } \\
\text { da moradia. }\end{array}$ & $\begin{array}{l}85 \% \text { of the participants must be housed in less than } 04 \\
\text { months after entering the project. }\end{array}$ & 4 \\
\hline $\begin{array}{l}\text { Financial contribution } \\
\text { of the participant }\end{array}$ & $\begin{array}{l}\text { The contribution of the participants for housing costs must } \\
\text { not exceed } 30 \% \text { of their income. }\end{array}$ & 4 \\
\hline Housing type & $\begin{array}{l}\text { Residential units in private market housing, inserted in } \\
\text { non-exclusive neighborhoods for people with mental health } \\
\text { support needs. }\end{array}$ & 4 \\
\hline Privacy & Private access to bedroom, bathroom and kitchen. & 3 \\
\hline $\begin{array}{l}\text { 2. Accessing and } \\
\text { keeping housing }\end{array}$ & & 3,5 \\
\hline $\begin{array}{l}\text { Control over individual } \\
\text { behaviors }\end{array}$ & $\begin{array}{l}\text { No requirement for adherence to drug treatments or other } \\
\text { behaviors such as abstinence, sobriety, use of medication, } \\
\text { stability of symptoms and non-criminal involvement. }\end{array}$ & 3 \\
\hline $\begin{array}{l}\text { Requirements signed in } \\
\text { the rental agreement }\end{array}$ & $\begin{array}{l}\text { The written agreements signed with the participants must } \\
\text { not contain items with responsibilities that go beyond the } \\
\text { occupation rules commonly practiced in the real estate } \\
\text { market, with the exception of the responsibility to maintain } \\
\text { the weekly meeting with the reference team. }\end{array}$ & 3 \\
\hline Re-house & $\begin{array}{l}\text { The project should offer new housing to the participants, in } \\
\text { case of conflict with the owner / tenant or other events that } \\
\text { lead to the loss of the previous home, with no limit on the } \\
\text { number of reallocations performed per participant. }\end{array}$ & 4 \\
\hline Follow-up & $\begin{array}{l}\text { In cases of housing loss, participants continues to receive } \\
\text { project services, including the support to search for other } \\
\text { housing alternatives. }\end{array}$ & 4 \\
\hline
\end{tabular}

to be continued... 


\begin{tabular}{|c|c|c|}
\hline $\begin{array}{l}\text { Dimension and } \\
\text { Criterion }\end{array}$ & Standards & $\begin{array}{l}\text { Score } \\
\text { obtained by } \\
\text { PCV }\end{array}$ \\
\hline $\begin{array}{l}\text { 3. Meeting the } \\
\text { assumptions of the } \\
\text { theoretical model }\end{array}$ & & 3,33 \\
\hline $\begin{array}{l}\text { Service choice and } \\
\text { support services } \\
\text { provided }\end{array}$ & $\begin{array}{l}\text { Participants must choose, refuse or change the intensity of } \\
\text { participation in the services provided in conjunction with } \\
\text { the network (health, social assistance, education and work), } \\
\text { with the exception of the weekly meeting with the reference } \\
\text { team. }\end{array}$ & 4 \\
\hline $\begin{array}{l}\text { No requirements for } \\
\text { participation in mental } \\
\text { health treatments }\end{array}$ & $\begin{array}{l}\text { Adherence to mental health services or to medication to } \\
\text { control symptoms should not be required. }\end{array}$ & 4 \\
\hline $\begin{array}{l}\text { No requirements } \\
\text { for participation in } \\
\text { substance use treatment }\end{array}$ & $\begin{array}{l}\text { Participation in CAPS AD or another treatment institution } \\
\text { to control drug use should not be required. }\end{array}$ & 4 \\
\hline $\begin{array}{l}\text { Harm Reduction } \\
\text { Approach }\end{array}$ & $\begin{array}{l}\text { Participants should not be required to stop using alcohol } \\
\text { and other drugs and staff works according to harm } \\
\text { reduction principles. }\end{array}$ & 3 \\
\hline $\begin{array}{l}\text { Areas covered by the } \\
\text { project intervention } \\
\text { (integrality). }\end{array}$ & $\begin{array}{l}\text { The project must offer actions at different levels of care, } \\
\text { according to the participants needs and contexts (mental } \\
\text { health, employment, education, satisfaction with housing, } \\
\text { religiosity, leisure). }\end{array}$ & 1 \\
\hline $\begin{array}{l}\text { Priority enrollment for } \\
\text { chronically homeless } \\
\text { people }\end{array}$ & $\begin{array}{l}\text { The project must assume, without restrictions, the care of } \\
\text { people with a long history of homelessness and who have } \\
\text { needs related to drug use and / or mental health. }\end{array}$ & 4 \\
\hline 4. Care management & & 2,0 \\
\hline $\begin{array}{l}\text { Person-centered } \\
\text { planning }\end{array}$ & $\begin{array}{l}\text { Development and review of an individualized plan, } \\
\text { containing specific care objectives and strategies, according } \\
\text { to the residents' preferences. }\end{array}$ & 1 \\
\hline Housing Support & $\begin{array}{l}\text { Offer services to help participants to move and maintain } \\
\text { housing, such as offering assistance with landlord, } \\
\text { neighborhood and community relations, financial planning } \\
\text { and shopping (furniture and household items). }\end{array}$ & 3 \\
\hline $\begin{array}{l}\text { Mental health } \\
\text { treatment }\end{array}$ & $\begin{array}{l}\text { Integration with mental health services, maintenance of } \\
\text { spaces for discussing cases, mutual recognition of services } \\
\text { organization. }\end{array}$ & 2 \\
\hline
\end{tabular}




\begin{tabular}{|c|c|c|}
\hline $\begin{array}{l}\text { Dimension and } \\
\text { Criterion }\end{array}$ & Standards & $\begin{array}{l}\text { Score } \\
\text { obtained by } \\
\text { PCV }\end{array}$ \\
\hline $\begin{array}{l}\text { Supported } \\
\text { employement services }\end{array}$ & $\begin{array}{l}\text { The project should maintain partnership with services } \\
\text { that supports participants to get income (paid work hours } \\
\text { through a scholarship associated with monitoring), creation } \\
\text { or expansion of projects of Solidarity Economy and / or } \\
\text { professional qualification. }\end{array}$ & 1 \\
\hline Educational services & $\begin{array}{l}\text { Offer training processes related to social rights. Support } \\
\text { inclusive education projects, such as adult literacy, digital } \\
\text { inclusion and others. }\end{array}$ & 2 \\
\hline $\begin{array}{l}\text { Support for social/ } \\
\text { community integration. }\end{array}$ & $\begin{array}{l}\text { The project must perform, at least, the following } \\
\text { actions: helping participants develop valued social roles } \\
\text { and networks inside and outside the project; helping } \\
\text { participants develop social competencies to successfully } \\
\text { negotiate social relationships; enhancing citizenship and } \\
\text { participation in social and political venues. }\end{array}$ & 2 \\
\hline $\begin{array}{l}\text { Respond to emergency } \\
\text { situations }\end{array}$ & $\begin{array}{l}\text { Capacity to meet participants urgent demands and connect } \\
\text { them to service network. }\end{array}$ & 2 \\
\hline $\begin{array}{l}\text { Monitoring } \\
\text { participants in cases of } \\
\text { hospitalization. }\end{array}$ & $\begin{array}{l}\text { In cases of hospitalization for health treatment, the staff } \\
\text { must assess, with the health service and the resident, the } \\
\text { need and objectives of the hospitalization, maintain follow } \\
\text { up, plan the discharge and meet other participants needs. }\end{array}$ & 3 \\
\hline 5. Work process & & 2,17 \\
\hline $\begin{array}{l}\text { Professional/Participant } \\
\text { Ratio }\end{array}$ & $\begin{array}{l}10 \text { or fewer participants per professional (full time } \\
\text { equivalent). }\end{array}$ & 3 \\
\hline $\begin{array}{l}\text { Contact with } \\
\text { participants }\end{array}$ & $\begin{array}{l}\text { Maintenance of weekly face-to-face contact with } 90 \% \text { of } \\
\text { participants. }\end{array}$ & 3 \\
\hline $\begin{array}{l}\text { Frequency of } \\
\text { organizational program } \\
\text { meetings for planning } \\
\text { and assessing the } \\
\text { activities }\end{array}$ & $\begin{array}{l}\text { The program staff must meet, at least twice a week, to } \\
\text { discuss, plan and evaluate the residents' follow-up plans. }\end{array}$ & 2 \\
\hline $\begin{array}{l}\text { Components of staff } \\
\text { meetings }\end{array}$ & $\begin{array}{l}\text { Brief review of relevant elements about the current situation } \\
\text { of all participants; record of progress and difficulties in } \\
\text { monitoring the participants; weekly schedule of activities } \\
\text { to be carried out by all team members; discussion of urgent } \\
\text { demands; definition of actions integrated the support network. }\end{array}$ & 1 \\
\hline
\end{tabular}

to be continued... 


\begin{tabular}{llc}
\hline \multicolumn{1}{c}{$\begin{array}{c}\text { Dimension and } \\
\text { Criterion }\end{array}$} & \multicolumn{1}{c}{ Standards } & $\begin{array}{c}\text { Score } \\
\text { obtained by } \\
\text { PCV }\end{array}$ \\
\hline $\begin{array}{l}\text { Peer specialist staff } \\
\text { with lived experience } \\
\text { of homelessness, use of } \\
\text { mental health services } \\
\text { and / or drug services. }\end{array}$ & $\begin{array}{l}\text { Staff must count on the support of peers who have a history } \\
\text { of overcoming the condition of social vulnerability, the } \\
\text { ability to mediate the relationship between participants and } \\
\text { public policies, facilitated by street language and culture. }\end{array}$ & 2 \\
\hline $\begin{array}{l}\text { Beneficiaries } \\
\text { participation in the } \\
\text { evaluation of the } \\
\text { project and in the } \\
\text { evaluation of the } \\
\text { homelessness policy. }\end{array}$ & $\begin{array}{l}\text { Project offers opportunities for participants input, in varied } \\
\text { types of activities, specific for evaluation purpose. }\end{array}$ & 2 \\
\hline & & \\
\hline
\end{tabular}

Source: the authors.

\section{What facilitated the implementation}

Despite the cultural and social distance between Brazil and the countries in which HF is used on a large scale - United States and Canada - the model is closely related to the principles and guidelines of the Brazilian mental health and drug policies, rooted around psychosocial rehabilitation, harm reduction and a community-based work.

The selection process of the professionals favored the formation of a team highly committed to the defense of homeless people's rights and identified with the principles and values of the project, promoting the establishment of bonds with the participants and reducing barriers resulting from the stigma and prejudice, normally associated with the profile of these target groups.

Linking the intervention to the social assistance department also appears as a facilitator, as it favored the granting of social allowances for the structuring and maintenance of housing, in addition to enabling the use of federal resources for renting residential properties, both government actions in the scope of the department. In turn, subcontracting a NGO allowed the rental of informal housing units - which made the majority of the houses rented by the project because of their lower market value. 


\section{What made implementation difficult}

High prices in the real estate market, associated with the low value made available by the project for each rental, made it difficult to provide houses in central areas with better access to public services, including transport. The stigma related to the profile of the project's participants generated resistance amongst owners and neighbors, constituting a barrier to the rental process and was also the main reason for relocating residents.

The team's lack of experience with drug addiction, associated with the low frequency of supervisory activities, continuing education and intersubjective institutional support made it difficult to implement the proposed care management model, especially concerning the team's capacity to carry out clinical case management and develop individualized therapeutic plans that include actions going beyond the provision of specific social assistance and health actions.

Still in relation to the professionals' work processes, it appears that the team was overloaded with the dual function of making the house rent (search for the property, negotiating with the owner, moving and managing the resource for furniture) and coordinating social programs in the area to support shared follow-up. A factor that seems to be aggravated by the precariousness of social policies network, which lack services and coordination between them.

\section{Conclusion}

The analysis of the degree of implementation allowed to identify that the project prioritized the inclusion of the target audience in individual houses, inserted in the community, respecting individual choice and the criteria of low-demand for access and permanence in the house, adopting the fundamental principles of the proposed model, that is, putting the concept of housing into practice first. In this sense, means were created to guarantee improvements in the living conditions of the beneficiaries of the project.

On the other hand, adjustments are needed to better structure the intervention, especially in ensuring minimum equipment for home furniture, training and supervision of the team, organization of the work process with definition of administrative and technical tasks, in addition to ensuring greater mobility of the team in the territories and strengthening the relationship with mental health and 
primary care services. Another issue to be faced is the need to ensure the composition of multidisciplinary teams with skills to meet the diversity of the residents' needs, as provided for in the HF model.

Among the limiting factors, the low offer of actions that go beyond the structuring and basic maintenance of housing and the promotion of access to social assistance and health services stands out, highlighting the challenge to fulfil the aim of social inclusion - the main result desired - especially regarding the integration of residents in spaces and experiences of income generation, social, political and cultural participation.

Enhancing the evidence on the interface between Housing and Social Inclusion is a fundamental issue for understanding the limits and possibilities of projects such as the one we analyzed. To elucidate the implications of this relationship, studies are needed to deepen the concept of social rehabilitation, in dialogue with the field of mental health. The investigation of concrete experiences of Housing First programs, in their original context, can provide useful lessons in addressing the weaknesses presented by the Brazilian intervention, given the proximity of the principles of the international model to the assumptions of the Brazilian social protection system, as identified in our analysis. ${ }^{1}$

\section{References}

ALVES, V. S. Modelos de atenção à saúde de usuários de álcool e outras drogas: discursos políticos, saberes e práticas. Cad. Saúde Pública, Rio de Janeiro, v. 25, n. 11, p. 2309-2319, nov. 2009.

ANDRADE, T. M. de. Reflexões sobre políticas de drogas no Brasil. Cien Saude Colet., v. 16, n. 12, p. 4665-4674, 2011.

BASTOS, F. I.; BERTONI, N. (Org.). Pesquisa Nacional sobre o uso de crack: quem são os usuários de crack elou similares do Brasil? quantos são nas capitais brasileiras? Rio de Janeiro: Fiocruz; 2014.

BOURGOIS, P. Useless Suffering: The war on Homeless Drugs Addicts. In: GUSTERSON, H.; BESTEMAN, C. (Eds.). The Insecure American. How we got here and what we should do about It Los Angeles: University of California Press; 2010. p. 238-254.

BRASIL. Ministério da Saúde. A política do Ministério da Saúde para a atenção integral a usuários de álcool e outras drogas. Ministério da Saúde. Brasília, 2004.

Ministério da Saúde. Política Nacional sobre Drogas. Brasília, 2005. 
BRANDÃO, C. R.; STRECK, D. R. Pesquisa participante: o saber da partilha. In: Pesquisa participante: o saber da partilha. Aparecida: Editora Ideias \& Letras; 2006.

CHAMPAGNE, F. et al. A análise de implantação. In: BROUSSELLE, A. et al (Orgs.). Avaliaçâo: conceitos e métodos. Rio de Janeiro: Editora Fiocruz; 2011a.

. Modelizar as intervenções. In: BROUSSELLE, A. et al (Orgs.). Avaliação: conceitos e métodos. Rio de Janeiro: Editora Fiocruz; 2011b.

CHEN, H.-T. Theory-driven evaluations. Beverly Hills: Sage, 1990.

CHENG, T. et al. Increases and decreases in drug use attributed to housing status among street-involved youth in a Canadian setting. Harm reduction journal, v. 11, n. 1, p. 12, 2014.

CSETE, J. et al. Public health and international drug policy. Lancet, v. 387, n. 10026, p. 14271480, Apr 2016.

DISTRITO FEDERAL. Decreto $n^{\circ}$ 35.191, de 21 de fevereiro de 2014. Regulamenta a Lei $\mathrm{n}^{\mathrm{o}} 5.165$, de 04 de setembro de 2013, que dispóe sobre os benefícios eventuais da Política de Assistência Social do Distrito Federal e dá outras providências. Brasília, 2014.

DIDENKO, E.; PANKRATZ, N. Substance use: Pathways to homelessness? Or a way of adapting to street life. Visions: BC's Mental Health and Addictions Journal, v. 4, n. 1, p. 9-10, 2007.

FITZPATRICK, S.; BRAMLEY, G.; JOHNSEN, S. Pathways into Multiple Exclusion Homelessness in Seven UK Cities. Urban Studies, v. 50, n. 1, p. 148-168, 2013.

FURTADO, J. P.; CAMPOS, R. O. Participação, produção de conhecimento e pesquisa avaliativa: a inserção de diferentes atores em uma investigação em saúde mental. Cad. Saúde Pública, Rio de Janeiro, v. 24, n. 11, p. 2671-2680, nov. 2008.

FURTADO, J. P. et al. A elaboração participativa de indicadores para a avaliação em saúde mental. Cad. Saúde Pública, v. 29, p. 102-110, 2013.

GARCIA, L. S. L.; KINOSHITA, R. T.; MAXIMIANO, V. Uma perspectiva social para o problema do crack no Brasil: implicaçóes para as políticas públicas. In: BASTOS, F. I. BERTONI, N. (Orgs.). Pesquisa Nacional sobre o uso de crack: quem são os usuários de crack e/ou similares do Brasil? quantos são nas capitais brasileiras? Rio de Janeiro: Editora ICICT/ FIOCRUZ, 2014, p. 147-157.

GOMES-MEDEIROS, D. et al. Política de drogas e Saúde Coletiva: diálogos necessários. Cad. Saúde Pública, Rio de Janeiro, v. 35, n. 7, 2019.

GOERING, P. et al. National at Home/Chez Soi Final Report. Calgary, AB: Mental Health Commission of Canada; 2014

HARTZ, Z. M. de A. Avaliação em saúde: dos modelos conceituais à prática na análise da implantação de programas. Rio de Janeiro: Ed. Fiocruz, 1997. 
HINO, P.; SANTOS, J. de O.; ROSA, A. da S. People living on the street from the health point of view. Revista brasileira de enfermagem, v. 71, p. 684-692, 2018.

LANCIONE, M.; STEFANIZZI, A.; GABOARDI, M. Passive adaptation or active engagement? The challenges of housing first internationally and in the Italian case. Housing Studies, v. 33, n. 1, p. 40-57, 2018.

LEAL, E. M.; FERRARI, I. F. A realidade social brasileira e o retrocesso na Saúde Mental. Rev. latinoam. psicopatol. fundam., São Paulo, v. 22, n. 3, p. 421-438, set. 2019.

LEJANO, R. Parâmetros para a análise de politicas: a fusão de texto e contexto. Campinas, SP: Ed. Arte Escrita, 2012.

MACNAUGHTON, E. et al. Implementing Housing First across sites and over time: Later fidelity and implementation evaluation of a pan-Canadian multi-site Housing First program for homeless people with mental illness. American Journal of Community Psychology, v. 55, n. 3-4, p. 279-291, 2015.

MARKHAM, A. N. The methods, politics, and ethics of representation in online ethnography. In: . The Sage handbook of qualitative research. Thousand Oaks, CA: Sage. 2005, p. 793-820.

MATS, B.; ARNE, G.; AKE, B. Prediction of Homelessness and Housing Provisions in Swedish Municipalities, European Journal of Housing Policy, v. 8, n. 4, p. 399-421, 2008.

MINAYO, M. C. S.; ASSIS, S. G. de; SOUZA, E. R. de. Avaliação por triangulação de métodos: abordagem de programas sociais. Rido de Janeiro: Editora Fiocruz, 2005.

NELSON, G. et al. Early implementation evaluation of a multi-site housing first intervention for homeless people with mental illness: a mixed methods approach. Evaluation and Program Planning, v. 43, p. 16-26, 2014.

PADGETT, D.; HENWOOD, B. F.; TSEMBERIS, S. J. Housing First: Ending homelessness, transforming systems, and changing lives. Oxford University Press, USA, 2016.

PIAT, M. et al. Pathways into homelessness: Understanding how both individual and structural factors contribute to and sustain homelessness in Canada. Urban Studies, v. 52, n. 13, p. 23662382, 2015.

RUI, T. Nas Tramas do Crack: Etnografia da abjeção São Paulo: Terceiro Nome, 2014.

VAN WIJK, L. B.; MÂNGIA, E. F. Atenção psicossocial e o cuidado em saúde à população em situação de rua: Uma revisão integrativa. Cien Saude Colet. Rio de Janeiro, v. 24, n. 9, fev. 2018.

PAULY, B. et al. Housing and harm reduction: what is the role of harm reduction in addressing homelessness? Int J Drug Policy, v. 24, n. 4, p. 284-90, jul 2013.

SICARI, A. A.; ZANELLA, A. V. Pessoas em Situação de Rua no Brasil: Revisão Sistemática. Psicol. cienc. prof. Brasília, v. 38, n. 4, p. 662-679, out. 2018. 
STEFANCIC, A. et al. The Pathways Housing First fidelity scale for individuals with psychiatric disabilities. American Journal of Psychiatric Rehabilitation, v. 16, n. 4, p. 240-261, 2013.

TABOL, C.; DREBING, C.; ROSENHECK, R. Studies of "supported" and "supportive" housing: A comprehensive review of model descriptions and measurement. Evaluation and program planning, 2010, v. 33, n. 4, p. 446-456.

TEIXEIRA, M. B.; ENGSTROM, E. M.; RIBEIRO, J. M. Revisão sistemática da literatura sobre crack: análise do seu uso prejudicial nas dimensóes individual e contextual. Saúde debate. Rio de Janeiro, v. 41, n. 112, p. 311-330, mar. 2017a.

TEIXEIRA, M. B. et al. Tensóes paradigmáticas nas políticas públicas sobre drogas: análise da legislação brasileira no período de 2000 a 2016. Ciênc. saúde coletiva. Rio de Janeiro, v. 22, n. 5, p. 1455-1466, maio 2017b.

TSEMBERIS, S. From streets to homes: An innovative approach to supported housing for homeless adults with psychiatric disabilities. J Community Psychol, 1999, v. 27: p. 225-241.

TSEMBERIS, S.; GULCUR, L.; NAKAE, M. Housing first, consumer choice, and harm reduction for homeless individuals with a dual diagnosis. American journal of public health, 2004, v. 94, n. 4, p. 651-656.

UNITED NATIONS OFFICE ON DRUGS AND CRIME. Social Cohesion, Social Disorganization and Illegal Drugs, International Narcotics Control Board. Report of the International Narcotics Control Board for 2011 (E/INCB/2011/1): New York, January 2012.

. Treatment and care for people with drug use disorders in contact with the criminal justice system. Draft pre-launch publication for initial circulation. March 2018.

WATSON, D. P. et al. Housing first and harm reduction: a rapid review and document analysis of the US and Canadian open-access literature. Harm reduction journal, v. 14, n. 1, p. 30, 2017.

\section{Note}

${ }^{1}$ A. P. Carvalho and J. P Furtado: design of the project, analysis and interpretation of data, writing, critical review and approval of the final version of the article. 


\section{Resumo}

Moradia assistida para pessoas em situação de rua no contexto da política de drogas brasileira: avaliação de implantação

Iniciativas de moradia assistida para pessoas em situação de rua vêm sendo desenvolvidas no Brasil, no âmbito da política de drogas brasileira, tendo como referência o modelo Housing First (Moradia Primeiro). Nesse contexto, é relevante analisar as influências das características locais no grau de implantação dessa modalidade de intervenção no cenário nacional. Para isso, realizamos análise de implantação, por meio de estudo de caso de projeto piloto de moradia assistida desenvolvido em Brasília-DF. Por meio de documentos oficiais, observação participante nos ambientes reais e virtuais, sistematização das perspectivas de trabalhadores e gestores responsáveis pela intervenção e modelização da proposta, caracterizamos a iniciativa. Em seguida, esta foi confrontada com critérios extraídos da proposta Housing First. Os resultados indicam a adequação da intervenção ao princípio fundamental de colocar a moradia em primeiro lugar, desvinculada de tratamento e abstinência, utilizando para isso soluçóes e adaptaçóes locais. Entretanto, carências no processo de gestão do cuidado integral e precariedade da rede de políticas sociais aparecem como desafios à transposição do componente de inserçáo social que constitui a proposta. A interface entre os setores Saúde e Assistência precisa ser mais bem analisada e a matriz inspiradora do projeto melhor conhecida em seu contexto de origem.

> Palavras-chave: habitação; saúde mental; mental; situação de rua; análise de implantação. 